\title{
Material Analysis and Conservation Treatment for Mother-of-Pearl Floor Mirror at Daejojeon Hall of Changdeokgung Palace, Korea
}

\author{
Su Zin Park | In Sun Hwang | Eun young Yoon* | Jang Jon Lee* | Ji Ae Song ${ }^{1}$ \\ Cultural Heritage Conservation Science Center, National Research Institute of \\ Cultural Heritage, Daejeon, 34122, Korea \\ *Conservation Science Division, National Research Institute of Cultural Heritage \\ Daejeon, 34122, Korea \\ ${ }^{1}$ Corresponding Author: ssong@korea.kr, +82-42-860-9383
}

\begin{abstract}
In this study, a scientific survey on the material of the mother-of-pearl floor mirror was conducted and conservation treatment processes were introduced. The survey results showed that the mother-of-pearl floor mirror in Daejojeon Hall of Changdeokgung is made of Dalbergia spp., and repair work seems to be done later with shorea spp. FT-IR analysis results showed that the varnishing is similar to the spectrum of lacquer. The metal wheels and metal line decorations set with mother-of-pearl were found to be made of brass based on XRF analysis, and the ingredient ratio showed that these were made in modern times. Foreign materials were stuck on the surface of the mother-of-pearl floor mirror before conservation treatment, which was in a structurally unstable condition owing to some missing submaterials. Conservation treatment was conducted on the damaged area to restore the mirror to its original appearance by using the same species of wood determined from the data obtained through the scientific survey.
\end{abstract}

Key Words: Floor mirror, Conservation, Changdeokgung Palace, Lacquer

\section{INTRODUCTION}

Daejojeon Hall of Changdeokgung Palace was a bedroom for a queen and it was designated as treasure No.816 in 1985. Daejojeon Hall was destroyed by fire in 1917 but it was reconstructed by using sub materials from Gyotaejeon of Gyeongbokgung Palace in the 1920s. During the reconstruction, western style wood mosaic floor, glass window, western style furniture, carpet, curtain were applied for indoor space(Park, 2013). Ancient furniture used in modern times including the bed used by the Empress Sunjeong of the Korean Empire was stored inside.

Furniture in Deajojoen hall has been exhibited for a long time, so it is structurally unstable of the surface contamination is severe. Therefore furniture need to doing conservation treatment for exhibition.

In general, modern and modern era have been made furniture are restoring focus on appearance based visual form and historical reference. The furniture of the Deoksugung Shogunjeon was also repaired this way(Cultural Heritage Administration, 2014). Scientific investigations should be preceded for more accurate restoration and repair.

This study intends to introduce the scientific analysis and conservation treatment process for material of the mother-of-pearl floor mirror which was displayed in Daejojeon Hall of Changdeokgung Palace.

\section{OBJECTION AND CONDITION}

\subsection{Objection}

The study object was the mother-of-pearl floor mirror displayed at Daejojeon Hall of Changdeokgung Palace. A floor mirror refers to a big mirror that can reflect the whole body. The size of the mirror was $2095 \times 905 \mathrm{~mm}$ and overall, the color was dark brown. Swallow-tailored weaving was 
applied to the mirror. The top ornament unit, mirror frame and bottom support surface were decorated with motherof-pearl. For mother-of-pearl decoration, the wood was carved in shape of mother-of-pearl for attachment. And a thin engraved line was made on the surface of the surface of mother-of-pearl to express details(Figure 1). Total length of the mirror was $330 \mathrm{~mm}$ and wooden frame encompasses the mirror. Wooden material and paper were inserted as a shock absorber between the mirror and the frame. In addition, the edge of the wooden material was decorated with metal line. The top of the bottom support was decorated with vine pattern using open work method and marble ornament in the shape of a pot in the middle. The front and rear side of the legs were carved to create paw of an animal and metal wheels were attached for mobility. These were the features of typical Chinese furniture and in fact there was a record that the furniture installed in Daejojeon Hall was imported from China(Kee, 2014)

\subsection{Before conservation condition}

Permanent exhibition is organized to make it possible to observe inside of Daejojeon Hall of Changdeokgung Palace by opening the door in the front side. Therefore, relics exhibited in Daejojeon Hall have been easily influenced by environmental changes. The mother-of-pearl floor mirror, which was displayed in such an unstable environment, had many pollutants accumulated such as dust from outside.

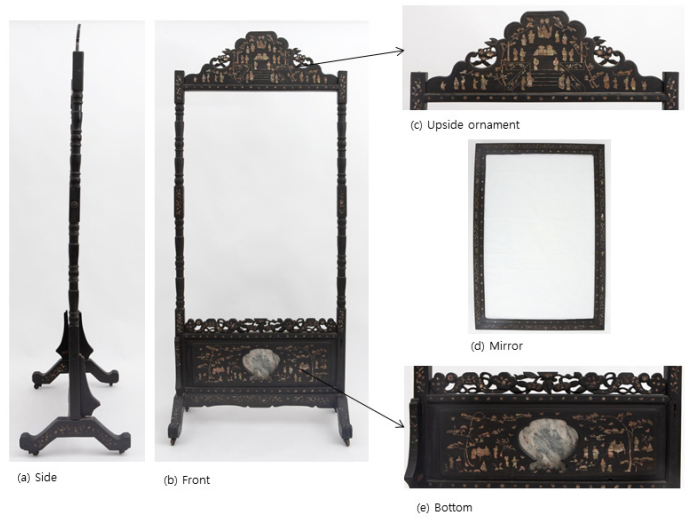

Figure 1. Before conservation condition.
And wooden material was deformed as mirror was hung for a long time bending the pillar(Figure 1a). In addition, overall surface was covered with yellow transparent material. The transparent material was assumed to be changed due to aging and stuck on the surface of motherof-pearl. Some of the mother-of-pearl ornaments were eliminated to the extent that the original surface of the wood was exposed and some part did not have a thin engraved line making it possible to assume that repair work was conducted later. The body and 4 connection materials that fix legs existed but the right side materials were lost in the front side and loosened. This made the whole structure be swayed, resulting in unstable structure. In addition, some wheels attached to legs were loosened to the extent that their function was lost.

\subsection{Disassemble}

The relic was in very unstable condition structurally so the whole parts were disassembled for observation. The disassembly results showed that the structure was divided into body, mirror, and legs.

The body was composed of the pillar that fixed the mirror and square shape support. The mirror was made as all-in-one type. At the top, flower shape ornament plate was inserted. The pillar was made to be a circular shape and only jonit parts had square pillar. The mirror frame and pillar were fixed using screws that made of metal. The wooden material was processed to be a circle shape to decorate head of the mirror.

The wooden material for mirror frame was made using

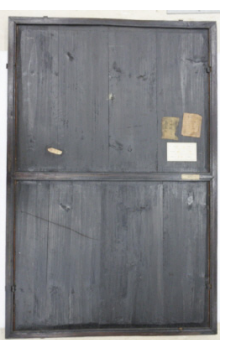

(a) Front

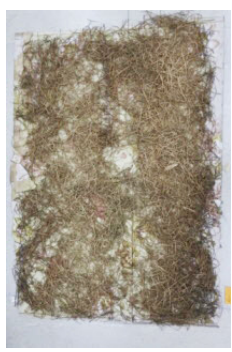

(b) Shock absorbing wood

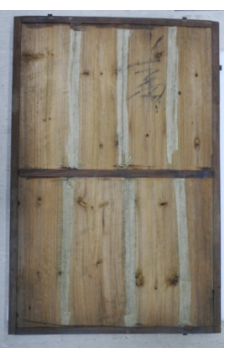

(c) Back
Figure 2. Detail photo of mirror back cover. 
mitre joint and mother-of-pearl and metal line were inserted on the surface for decoration. Mirror was connected to the inside of the frame and wooden materials in the shape of a thin rope was put(Figure 2a) and paper was applied(Figure $2 b)$. Then wooden cover was inserted(Figure 2c). The wooden material in rope shape seemed to play the role of shock absorbing material to protect the mirror. The back cover has the basic frame in the shape of $日$ and rectangular plate was attached within the frame. The traditional paper was attached for joint area for fixation and some area on the traditional paper was ripped. The cover had two fixing devices that connects each face with the mirror frame. The device on the left bottom was lost. The fixing device at the top was fixed and others can be attached and detached. The orange coating material was applied on the backside of the mirror and some part of edges had peeled off coating material.

There were two legs and they were made not to be separated by inserting sub materials in the same width and length of the body support on the front and back(Figure 3). At the base of the legs was attached with metal wheels. The wheels were made to rotate in every direction(Figure 4).

\section{SCIENTIFIC ANALYSIS}

\subsection{Methods of analysis}

\subsubsection{Identification wood}

Wood species identification was conducted to find out the type of wood used for the floor mirror and restore

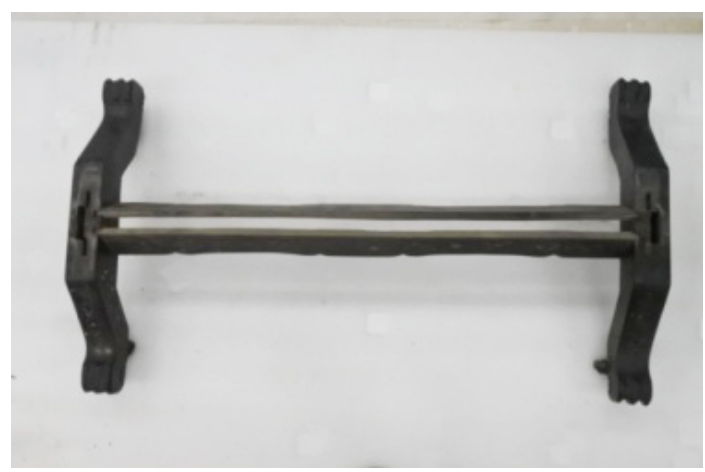

Figure 3. The leg of mother-of-pear floor mirror. missing parts. The wood species identification used wood pieces separated from disassembly process and wooden materials that remain in the groove of missing materials. In addition, species identification was conducted for wood which served as a shock absorption material inside the mirror frame. The collected samples were made into thin sections using a razor blade and observed using a microscope(Eclipse Ni-E, Nikon, Japan). The photo of cell characteristics was taken. The identification of wood refer to ${ }^{\mathbb{T}}$ The organization and identification of $\operatorname{wood}_{\Perp}$ (Park, $1987)$ and ${ }^{『} I N S I D E W O O D 』(N C$ State University, 2019).

\subsubsection{Fourier-transform infrared spectroscopy $(F T-I R)$}

FT-IR analysis was conducted to check the composition of surface varnishing. As it was hard to take samples for varnishing analysis, a mobile FT-IR spectrometer(Agilent 4300, Agilent technologies, USA), which made it possible to analyze without any specific pre-treatment, was used. ATR(Attenuated total reflection) method was used for analysis. The analysis condition was to scan resolution $8 \mathrm{~cm}^{-1} 32$ times within the scope of $4000 \sim 650 \mathrm{~cm}^{-1}$.

\subsubsection{Portable $X$-ray fluorescence analysis( $p-X R F)$}

To check the composition of metals used for metal lines and metal used for wheels, portable X-ray fluorescence analyzer(Olympus, DELTA, USA) was used for analysis. Analysis condition was 10 40 kV, 80 200 $\mu \mathrm{A}$, Rh Target and Silicon Drift Detector was used. The analysis time was 60 seconds in Alloy Mode and spot size was $15 \mathrm{~mm}$.

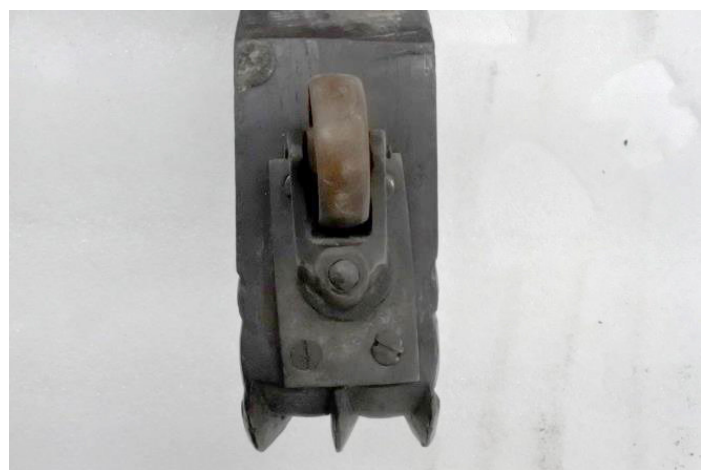

Figure 4. Metal wheel. 


\subsection{Results of analysis}

\subsubsection{Identification wood}

The wood species identification results showed that the body was made of Dalbergia spp. and materials for leg connection, which was assumed to be repaired later was made of shorea spp. In addition, the thin wooden materials which serve as a shock absorber within the mirror were found to be made of Picea spp..

\section{(1) Body}

Cross-sectional view confirmed vessels and most of them were made of wood fiber. The shape of the conduits was circle and solitary pores and radial pore multiple for which 2 were attached existed together. Gum materials were found in the vessel(Figure 5a). Tangential sectional view showed 1-2 rows in radial structure and cells were arranged in store element type. The shape of perforation was simple perforation and intervascular pitting had alternate pitting(Figure $5 \mathrm{~b}$ ). Radial sectional view showed homogeneous ray tissue composed of only procumbent ray cell. Crystalliferous cell was confirmed in radial parenchyma cell(Figure $5 \mathrm{c}$ ). Based on these characteristics the materials were identified to be Dalbergia spp. among Papilionideae.

\section{(2) Materials for leg connection}

In the cross-sectional view, pores were diffuse and most of them were solitary pores. Axial parenchyma cell was banded apotracheal parenchyma(Figure 6a).

Tangential sectional view showed 3 to 4 rows mostly for radial structure and cell height was $12 \sim 15$. The perforation was simple perforation and intervascular pitting had alternate pitting(Figure 6b). Radial sectional view showed homogenous ray tissue composed only of procumbent ray cells. Gum materials were filled in the ray cell(Figure 6c). Based on this characteristics, the species was identified to be shorea spp..

(3) Wood to absorb shocks inside the mirror

The cross sectional view confirmed that it was soft wood

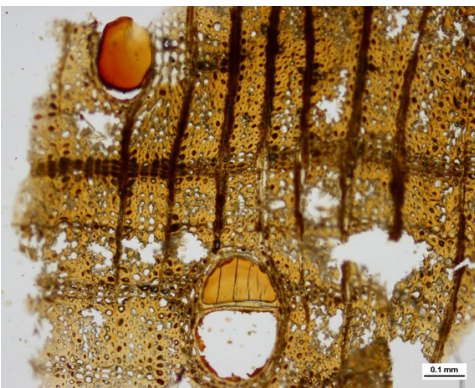

(a) Cross section

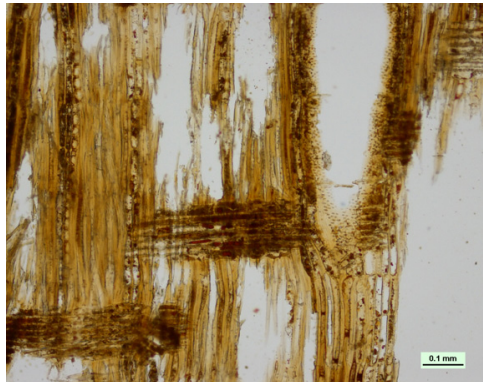

(b) Radial section

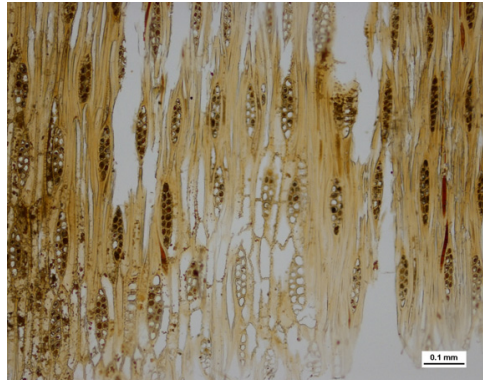

(c) Tangential section

Figure 5. Micrographs of Dalbergia spp..

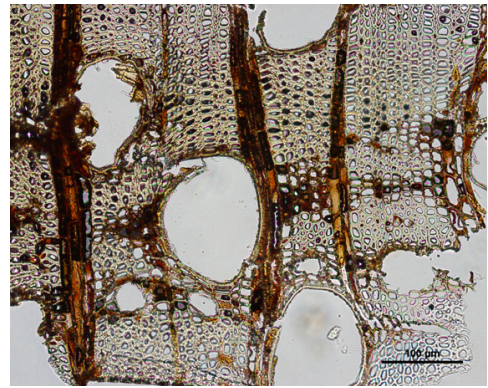

(a) Cross section

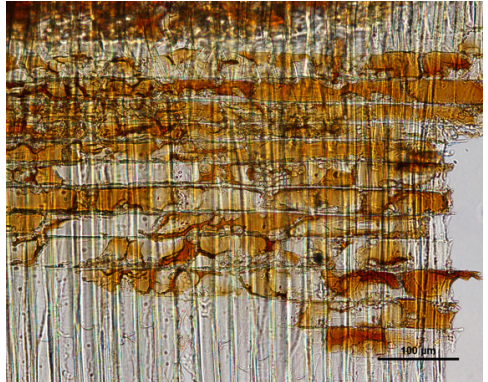

(b) Radial section

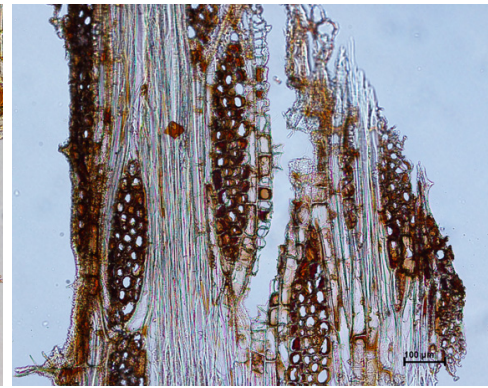

(c) Tangential section

Figure 6. Micrographs of Shorea spp.. 
composed of tracheid. The movement into latewood and earlywood was gradual(Figure 7a). Tangential section showed fusiform ray and uniseriate ray. The height of radial tissue on tangential section was 3 to 5 cell height on average (Figure $7 b$ ). Radial section shows the shape of cross field fitting is mixture of cupressoid pit and piceoid pit. 3 to 4 pittings existed in one area. Bordered pit is mostly 1 row. Nodular end wall was significantly developed in the simple pit of end wall(Figure 7c). Based on this characteristics they were identified to be Picea spp. among Pinaceae.

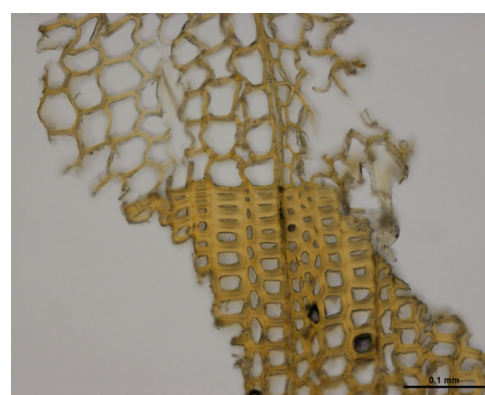

(a) Cross section

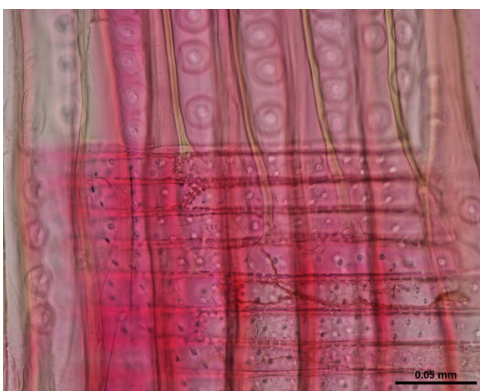

(b) Radial section

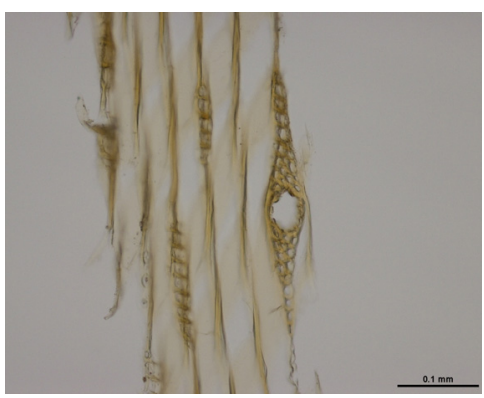

(c) Tangential section

Figure 7. Micrographs of Picea spp..



Figure 8. Result of FT-IR.
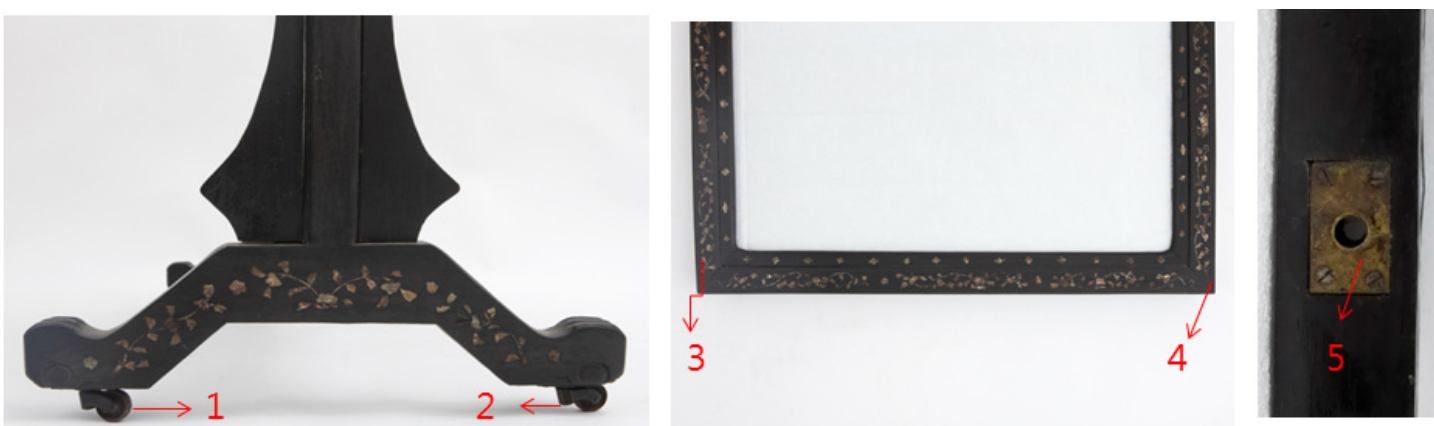

Figure 9. p-XRF analysis position. 
3.2.2. Fourier-transform infrared spectroscopy(FT-IR)

The analysis results showed the legs of the mirror and top ornament parts showed the pattern similar to lacquer spectrum. The infrared spectrum of the legs and top ornament parts showed $3100-2800 \mathrm{~cm}^{-1}$ of C-H stretching vibration, $1740-1650 \mathrm{~cm}^{-1}$ of $\mathrm{C}=\mathrm{O}$ stretching vibration, $1480-1300 \mathrm{~cm}^{-1}$ of C-H bending vibration, and $750-700 \mathrm{~cm}^{-1}$ of $\mathrm{C}-\mathrm{H}$ torsional vibration in common(Figure 8).

\subsubsection{Portable $X$-ray fluorescence analysis( $p-X R F)$}

$\mathrm{p}$-XRF analysis results showed that they are composed mostly of copper and zinc with small amount of lead. In addition very small amount included iron(Fe), tin( $\mathrm{Sn})$, Nickel(Ni). The content ratio of the elements were found differently depending on the location of measuring samples (Table 1, Figure 9).

\section{CONSERVATION}

\subsection{Cleaning}

Overall dry cleaning and wet cleaning were conducted at the same time. Small tools such as an air blower and a brush were used to light foreign materials attached to the surface. Nacre cutting knife was used to remove yellow materials stuck on the wood surface physically for thick area and ethanol 50 wt.\%(in water) was used for thin area. The cleaning for mother-of-pearl was done using nacre cutting knife and magnifier to remove only pollutants and second cleaning was conducted using distilled water. Ethanol $50 \mathrm{wt} \%$ (in water) was used for cleaning marble decoration located at the center of body support(Figure 10).

\subsection{Restoration and reinforcement treatment}

Based on the results of wood identification, leg connection was made using Shorea spp.(lauan). The wood processing was conducted by Hyundae Buddhist Sculpture Center, a service team for Changdeokgung management office. The restored materials were finished with lacquer varnishing to be in harmony with the relic. Lacquer and refined lacquer were done for 2 times respectively conducting varnishing for 4 times in total for making similar color.

Table 1. Results of $\mathrm{p}-\mathrm{XRF}$

\begin{tabular}{cccccccc}
\hline \multirow{2}{*}{$\begin{array}{c}\text { Serial } \\
\text { No. }\end{array}$} & \multirow{2}{*}{ Sample location } & \multicolumn{5}{c}{ Element detected (\%) } \\
\cline { 3 - 8 } & & $\mathrm{Cu}$ & $\mathrm{Zn}$ & $\mathrm{Pb}$ & $\mathrm{Sn}$ & $\mathrm{Fe}$ & $\mathrm{Ni}$ \\
\hline 1 & Right side rear wheel & 67.8 & 31.3 & 3.17 & 1.41 & 0.79 & 0.46 \\
\hline 2 & Right side front wheel & 60.5 & 33.4 & 3.24 & 1.55 & 0.66 & 0.48 \\
\hline 3 & Left side metal line & 58.1 & 33.6 & 4.83 & 1.54 & 4.22 & 0.48 \\
\hline 4 & Right side metal line & 60.4 & 25.5 & 2.71 & - & 3.82 & 0.08 \\
\hline 5 & Hinge & 54.8 & 28.3 & 10.7 & 0.68 & 5.19 & 0.29 \\
\hline
\end{tabular}

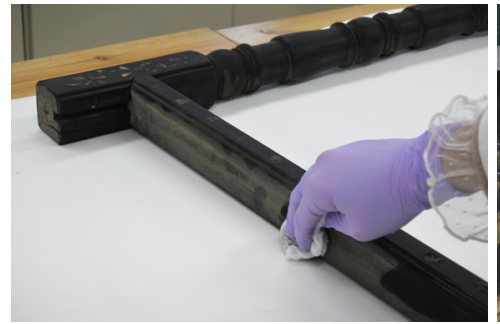

(a) Wood surface cleaning

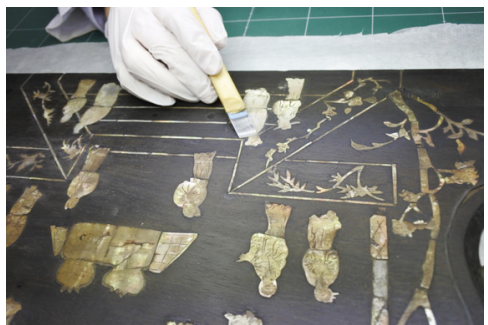

(b)Mother-of-pearl cleaning

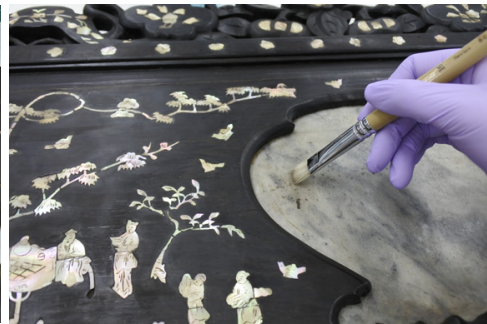

(c) Marble cleaning

Figure 10. Cleaning. 
The treatment was done focusing on lost and damaged cover and exfoliated coating material on the glass. The coating material of mirror peeled off at the edge was bonded using Parloid B72 10 wt.\%(in acetone). In addition,

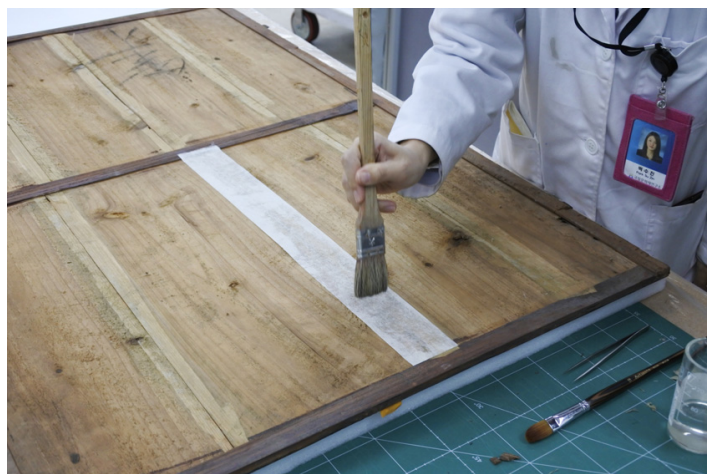

Figure 11. Attaching new paper in mirror back cover. it was applied to the crack to prevent peeling. It was decided to replace the traditional paper which was attached to the inside of back cover as it was damaged significantly. The existing traditional paper was removed slowly after



Figure 12. Making mirror connection chock.

Table 2. Detail photo of conservation before\&after

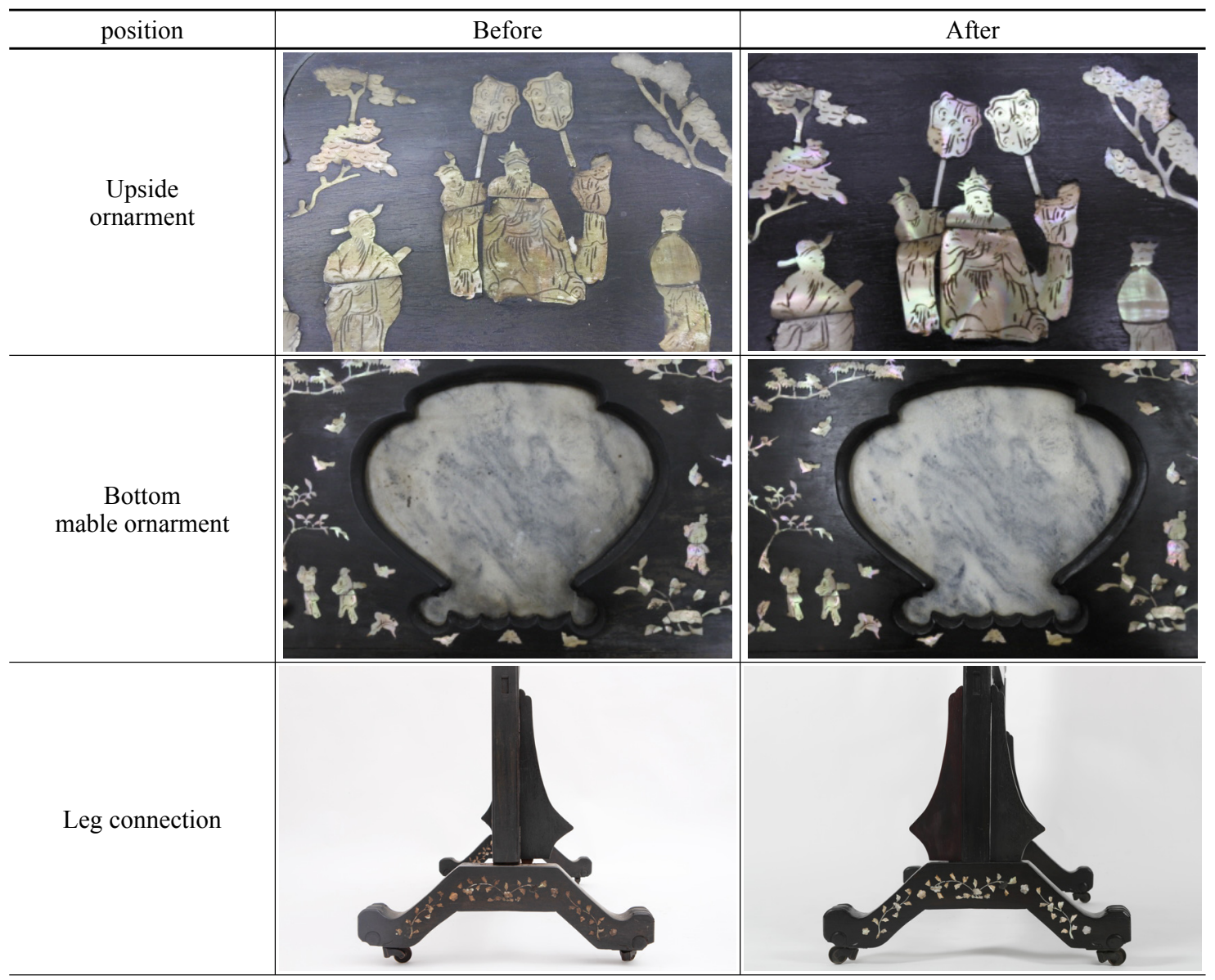


making it humid. After the removal, wheat starch glue was used for attaching mulberry paper(Figure 11). The materials lost from the mirror cover was made using bamboo and color was matched by using acrylic painting(Figure 12). The wood shock absorber and paper included in the mirror was aged. Therefore, they were removed and replaced by DuPont ${ }^{\circledR}$ paper, which has high stability.

The wheels attached to the legs were weakened with deformation of metal for long term use. The original function of the wheels was lost. To solve this problem, the wheels were disassembled and reinforced. The lead strap was used for metal part to fix the loosened area after disassembly.

\subsection{Surface treatment and reassembly}

In the future, the floor mirror at the Daejojeon Hall, Changdeokgung will be exhibited outside. Therefore, surface treatment was conducted considering the impact of external environment. For surface treatment, Carnauba wax was used. Carnauba wax is a natural wax extracted from palm trees. Wax brush and fine-fiber cloth were used for thin application on the surface. After surface treatment, reassembly was done in the opposite order of disassembly. The restored materials were inserted.

\subsection{After conservation condition}

Foreign materials stuck on the surface were all removed after conservation treatment. In particular, the unique color of mother-of-pearl was restored by removing pollutants stuck on the surface.

The function of wheels was restored with reinforcement as they were damaged due to long-term use and non-management. The lost materials were restored and assembled to make a structurally safe condition resulting in now swing.

The wood, which shock absorber in the mirror, was removed and DuPont ${ }^{\circledR}$ paper was used as it can serve as a shock absorption material.

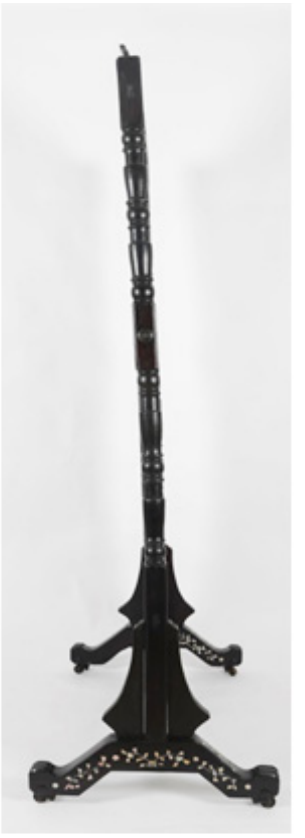

(a) Side

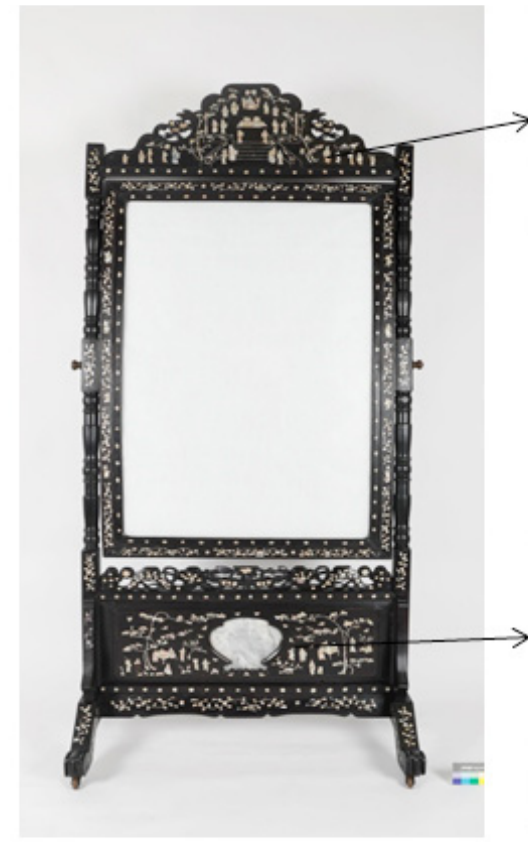

(b) Front

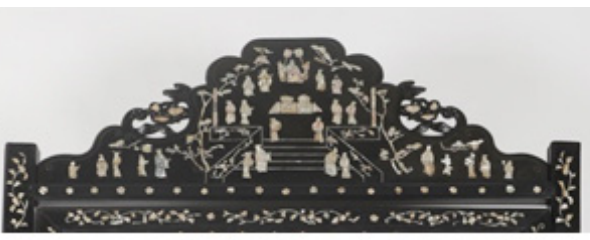

(c) Upside ornament

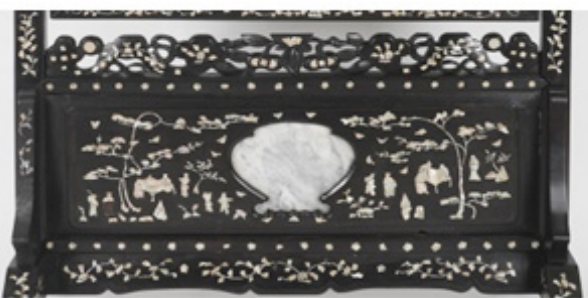

(d) Bottom

Figure 13. After conservation condition. 


\section{CONCLUSION AND DISCUSSION}

In this study, a scientific investigation was conducted for materials of the floor mirror displayed at Daejojeon Hall of Changdeokgung and conservation treatment results were announced. There was a record that the mother-of-pearl floor mirror was imported from China and it was confirmed that it was Chinese furniture based on overall style and material survey results.

It was confirmed that the Dalbergia spp.(rose wood) and Shorea spp.(lauan) wood were used to make the motherof-pearl floor mirror. Dalbergia spp.(rose wood) was used for premium furniture in China. Rose wood is strong and has a good color. China has made furniture by importing ebony and rose wood from Southeast Asia since Ming Dynasty(Lee, 2015). It was confirmed that lauan wood was used for materials that connected the body and legs. The wood of Shorea spp. has red brown color and wood grain is light. Lauan wood has red brown color and even wood grain. Usually they are grown in Southeast Asian countries such as the Philippines and Indonesia. Usually, they are used for plate and construction materials(Kim, 2003). The wood used for buffer inside the mirror frame was Picea spp. has a yellow white color and is light. It is used for musical instrument and pulp wood(Lee, 1997).

As such it is estimated that the reason why the material for body and connection material are different is that repair was done in the later era. In fact, the mother-of-pearl decorated for connection material is different from mother-of-pearl on the body as it is directly attached to the surface.

Top of the wood was dark brown. This dark brown surface was analyzed using FT-IR and the result showed $3100-2800 \mathrm{~cm}^{-1}$ of C-H stretching vibration, $1740-1650 \mathrm{~cm}^{-1}$ of $\mathrm{C}=\mathrm{O}$ stretching vibration, $1480-1300 \mathrm{~cm}^{-1}$ of $\mathrm{C}-\mathrm{H}$ bending vibration and $750-700 \mathrm{~cm}^{-1}$ of $\mathrm{C}-\mathrm{H}$ torsional vibration in common. It is found that such a spectrum was very similar to that of lacquer sample.

The decoration line of the mirror frame and wheels were made of metal. They were analyzed using $\mathrm{p}-\mathrm{XRF}$ and the result showed that they were brass mainly composed of copper $(\mathrm{Cu})$ and $\operatorname{zinc}(\mathrm{Zn})$. In addition, small amount of lead included. Depending on analysis location, element content ratio was different.

The ratio of zinc( $\mathrm{Zn})$ in these subjects is around $30 \%$ in average. In general, as brass including zinc $(\mathrm{Zn})$ in $30 \sim 40 \%$ has high strength, it is used in producing plates, poles, pipes and so on, and as a casting material(Kwon, 2008). The mirror hinge was higher than the metal at other positions by more than $10 \%$ of $\mathrm{Pb}$ content. In most cases, lead $(\mathrm{Pb})$ in $0.5 \sim 3.5 \%$ is added to improve strength of brass. It can be seen that it was made in modern times through the inclusion of nickel(Kim et al., 2011)

Dry cleaning was conducted using air blower and brush for conservation treatment and partial wet cleaning was conducted. Ethanol 50 wt.\%(in water) was used to remove thick transparent materials on the surface. Ethanol dissolved only pollutants without damaging wood surface and lacquer. After cleaning, unique color of mother-of-pearl and surface of the mirror appeared. The structurally unstable area due to missing materials was restored using the same kinds of wood based on wood species identification. After restoration reassembly was done to make the structure stable(Figure 13).

In this study, the type of materials used and production methods were identified by conducting a scientific study and conservation treatment for the floor mirror which was exhibited at Daejojeon Hall of Changdeokgung Palace.

The wood mainly used for the production of the floor mirror is the Dalbergia spp., which is the wood used as high quality furniture in China

Korean lacquer wares made in modern times have characteristics of attaching mother-of-pear directly on the wood surface with black lacquer. On the contrary, the floor mirror inlaid with mother-of-pear used the method of processing wood surface to make the shape of the mother-of-pearl.

The results of investigation confirmed that the mother-of-pearl floor mirror that it was Chinese style, which is consistent with the records in the literature that they were imported from China.

Composition wood of floor mirror that Dalbergia spp., 
Shorea spp. and Picea spp.. Body, leg connection and mirror absorb shocks are made using different species wood.

Generally, species that are often used in the production of Chinese furniture include high strength such as Dalbergia spp.(rose wood), Diospyros ebenum(ebony), Dalbergia odoriferous(Huanghuali). On the other hand, shorea spp.(red lauan). and picea spp. are light weight and low strength. especially picea spp. live in alpine district

The use of wood with different materials and physical properties is likely to have been replaced during later repairs. Like this, the modern furniture many repaired during using and maintain. so that scientific investigation based distinguish between repair part and original part.

The data found through this study is considered to be helpful in managing and conducting conservation treatment for Chinese furniture imported during modern times.

\section{ACKNOWLEDGEMENT}

This study was funded by the Cultural Heritage R\&D Project(The Conservation and Investigation of Organic Cultural Heritage) of the National Research Institute of Cultural Heritage, Cultural Heritage Administration and we are deeply grateful for their administrative and financial support.

\section{REFERENCES}

Cultural Heritage Administration, 2014, Survey and repair report of Deoksugung Seokjojeon. (in Korean)

Kee, S.H., 2014, Study on the deformation of the Changdeokgung in the early 20th century : focused on the areas of Injeongjeon, Huijeongdang and Daejojeon. Master's thesis, Korea National University of Arts, Seoul, 64-65. (in Korean with English abstract)

Kim, S.H., 2003, An illustrated imoport wood. Joongangbook, Seoul. (in Korean)

Kim, S.Y., Joo, C.S. and Jung, B.H., 2011, Introduction to brass engineer. Munundang, Seoul, 58-59. (in Korean)

Kwon, H.C., 2008, Understand of cupper and cupper alloy. S\&M Media, Seoul, 100-112. (in Korean)

Lee, P.W., 1997, Properties and uses of korean wood. Seoul National University Publishing Department, Seoul. (in Korean)

Lee, S., 2015, Study on the manufacturing techniques of the traditional Chinese furniture. Master's thesis, Kongju National University, Gongju, 16-17. (in Korean with English abstract).

NC State University, 2019, Inside wood. http://insidewood.lib. ncsu.edu/search (January 7, 2019)

Park, S.J., Lee, W.Y. and Lee, H.W., 1987, The organization and identification of wood. Hyangmunsa, Seoul, 113. (in Korean)

Park, S.K., 2013, A study on the modern transformation of royal palaces during the Japanese Ruling Era : focused on Huijeongdang in Changdeokgung Palace. Master's thesis, Hanyang University, Seoul, 22. (in Korean with English abstract) 